\title{
\#10
}

\section{Tantangan Merawat Idealisme dalam Industri Media Online di Indonesia}

\author{
Lamria Raya Fitriyani
}

Mendengar kata idealisme selalu terlintas mengenai kebenaran yang harus dipahami dan dipatuhi. Hampir seluruh sektor maupun organisasi termasuk dalam lingkup individu menjadikan gagasan dan pemikiran pada idealisme sebagai pengawas dalam melaksanakan setiap perencanaan. Sehingga jika ditemukan pelanggaran atau kesalahan yang dilakukan, maka secara langsung dianggap bahwa hal tersebut sudah tidak bisa dikatakan sebagai sesuatu yang ideal.

Jika merujuk kepada pengertian idealisme itu sendiri, idealisme merupakan cita-cita, obsesi, sesuatu yang harus dikejar untuk bisa dijangkau dengan segala daya dan cara yang dibenarkan menurut etika dan norma profesi yang berlaku, serta diakui oleh masyarakat dan negara (AS, 2006). Sehingga dari pengertian tersebut kita bisa 
memahami bahwa idealismelah yang dijadikan dasar dalam melakukan setiap aktifitas dan kegiatan setiap profesi, termasuk pada profesi jurnalis dan industri media.

Merujuk pada Undang-Undang Pers No.40 tahun 1999, disampaikan bahwa pers sudah menduduki kebebasannya dalam melakukan seluruh fungsi dan aktifitas pers itu sendiri, yaitu dapat memberikan informasi, mengedukasi, menghibur dan kontrol sosial. Disamping itu fungsi dari media massa juga sebagai lembaga ekonomi. Sehingga jika sebelum reformasi idealisme pers terbelenggu, dibatasi dan harus menyesuaikan dengan agenda pemerintahaan, maka setelah reformasi idealisme pers sampai saat ini bebas berekspresi (Martini, 2014).

Idealisme pers merupakan sebuah amanah yang menjadi arah dalam pelaksanaan setiap media, baik media elektronik, media cetak maupun media online. Berawal dari sejarah Indonesia yaitu dimulainya gerbang awal kebebasan pers di Indonesia, maka terbentuklah keseragaman idealisme pers yang menjadi pagar pengawas setiap industri pers. Sehingga perwujudan dari kepatuhan idealisme pers itu sendiri adalah adanya kemampuan dalam menjalankan setiap fungsi tersebut secara seimbang.

Selain itu, idealisme pers selalu berdekatan dengan bagaimana kualitas informasi dan berita yang disampaikan pada media itu sendiri, dan inilah mengapa masyarakat yang menjadi konsumen media, memberikan perhatian yang sangat luar biasa kepada industri media. Mengingat pers adalah harapan dan sumber yang bisa dipercaya oleh masyarakat dalam mendapatkan informasi dan berita terbaru, sehingga setiap penikmat media mempunyai harapan dalam setiap perkembangannya.

Pada kesempatan ini, penulis akan memfokuskan kepada idealisme media online. Selalu ada yang menarik jika membahas mengenai digitalisasi yang begitu pesatnya, sehingga membuat media juga 
mau tidak mau harus beradaptasi dengan perkembangan arus informasi saat ini. Ya, media online adalah media termuda dibandingkan media-media pendahulunya. Tetapi, walaupun termuda, media online cepat untuk meraih pembacanya. Menurut data Dewan Pers, jumlah media online di Indonesia tahun 2019 sudah mencapai 47.000 media dengan hanya 2.400 media online yang sudah terdaftar di Dewan Pers (Rizkinaswara, 2019).

Media online yang sudah mendapatkan verifikasi dari Dewan Pers sebagai lembaga idependen, tentu memiliki ekspektasi dan harapan tersendiri dibandingkan media online lainnya yang belum secara resmi mendapatkan verifikasi. Secara langsung, pembaca akan lebih mempercayai setiap berita yang disampaikan oleh media tersebut dibandingkan dengan media yang belum melewati seleksi verifikasi

Pada industri media online terdapat persaingan yang sangat ketat untuk menarik perhatian pembaca masuk ke dalam laman pemberitaannya. Banyaknya jumlah klik yang diperoleh akan menentukan kuantitas dari pemasukan iklan masing-masing. Mengingat aspek komersialisme industri media sangat bergantung kepada slot iklan yang ditawarkan kepada para investor, maka, media berlomba-lomba menampilkan informasi dari berbagai sudut pandang secara terus menerus.

Akan tetapi banyak informasi atau pemberitaan yang menunjukkan ketimpangan dan ketidakberhasilan media online dalam menjalankan fungsi dan tujuan pers sesuai idealismenya. Hal ini terjadi karena mereka tidak dapat menyeimbangkan antara idealisme dan komersialisme yang mereka lakukan. Mayoritas media online sibuk dalam mengedepankan judul berita dibandingkan dengan relevansi isi berita itu sendiri. Hal ini tentu untuk mengundang ketertarikan pembaca dibandingkan penggunaan judul yang biasa aja. Judul yang menggunakan 
clickbait lebih memanfaatkan sisi emosional dari pembaca berita tersebut karena adanya kesenjangan antara apa yang diketahui dan apa yang ingin diketahui, termasuk kesenjangan pengetahuan (information gap) (Hadiyat, 2019).

Salah satu media yang ramai diperbincangkan karena judul beritanya dianggap clickbait, yaitu pemberitaan pada media kompas.com dengan judul "Hanya WNA China yang diberi Izin Tinggal Darurat di Indonesia karena Virus Corona", pada pemberitaan tanggal 12 Maret 2020. Judul tersebut secara langsung menyampaikan bahwa adanya perlakuan khusus dari Indonesia kepada WNA China. Bagi pembaca yang tidak membaca isi beritanya, hanya dengan judulnya akan memiliki asumsi dan persepsi yang negative. Padahal isi berita dari judul tersebut menyampaikan pernyataan Kepala Kantor Imigrasi Non TPI Kelas 1 Tanggerang, bahwa hanya WNA China yang diperbolehkan mengajukan izin tinggal darurat di Indonesia dikarenakan tidak ada penerbangan dari Indonesia ke China saat itu (Wiryono, 2020).

Judul yang digunakan dan isi berita tersebut sesungguhnya memiliki makna yang berbeda. Mengapa hal itu terjadi? Jawabannya, karena media tersebut menggunakan strategi clickbait agar lebih menarik pembaca untuk mengklik judul pemberitaan, pembaca hanya puas dengan judul tersebut tanpa ingin mencari maksud informasinya dengan detail. Hal ini juga selaras dengan kondisi yang cukup memprihatinkan yaitu tingkat literasi media pada masyarakat tidak berbanding lurus dengan tingginya penggunaan internet.

Menurut Silverman (dalam Hadiyat, 2015), masih banyaknya pembaca yang kurang mengetahui akan berita hoax, sarkasme, dan juga memiliki kebiasaan untuk tidak membaca artikel berita secara utuh. Mereka hanya membaca judul artikel beritanya saja dan langsung menyimpulkan. Sedangkan media yang membuat artikel 
clickbait sering menyesatkan pembaca dengan judul yang tidak diverifikasi, dan juga jarang utuk dikoreksi.

Kondisi ini tentu sejalan dengan salah satu fungsi pers, yaitu untuk memberikan informasi kepada publik. Fungsi dan peran pers untuk memberikan informasi bukan hanya sekedar berlomba-lomba menayangkan artikel berita, dengan judul yang menarik perhatian atau kontroversial akan tetapi tidak ada kolerasi atau tidak ada kesesuaian antara judul dengan peristiwa yang diberitakan. Media online seharusnya berhati-hati dan lebih memikirkan dampak dari setiap pemberitaan yang ditayangkan pada situs-situs mereka, termasuk ketika mengangkat berita-berita yang sensitif bagi masyarakat.

Bukan rahasia lagi jika pengguna clickbait dikarenakan semakin ketatnya persaingan antar media online saat ini. Fenomena penggunaan clickbait ini secara langsung menunjukkan adanya tuntutan dari pemilik media kepada para jurnalis tidak hanya menghasilkan artikel yang mendapatkan key performance indicator (KPI) yang tinggi akan tetapi juga harus menghasilkan artikel yang bersifat komersial untuk keberlangsungan bisnis medianya, dengan kata lain jurnalis dituntut untuk dapat memenuhi Kode Etik Jurnalistik. Akan tetapi, yang terjadimedia terlihat lebih mengedepankan KPI (Kertanegara, 2018).

Media online dengan tuntutan yang serba cepat untuk menjadi terdepan dalam memberikan sebuah pemberitaan, tidak jarang didapati tidak selaras dengan prinsip keakuratan dalam berita. Tentunya jika merujuk kepada 2.400 media online yang sudah mendapatkan verifikasi Dewan Pers, idealnya keakuratan dalam pemberitaan sudah menjadi sebuah kewajiban yang harus dipatuhi, karena peran pers yang berfungsi untuk memberikan berita, tentu disertai dengan kebenaran akan berita tersebut. 
Selain itu, pada Kode Etik Jurnalistik dimuat pula, pasal 1 yang berbunyi, "Wartawan Indonesia bersikap independen, menghasilkan berita yang akurat, berimbang dan tidak beritikad buruk" (Dewan Pers, 2017). Sehingga hal ini jelas bahwa selain merujuk pada UUD Pers No.40 tahun 1999 yang menjelaskan fungsi dan peran pers, seorang wartawan juga bertanggung jawab atas kode etik profesinya. Hal tersebut juga mendukung tuntutan bahwa setiap media online wajib memperhatikan dengan detail setiap artikel pemberitaan serta mengecek secara berulang sebelum ditayangkan pada setiap laman situsnya.

Salah satu kasus pelanggaran Kode Etik Jurnalistik pada tahun 2019, adalah ketika Dewan Pers memutuskan bahwa Indopos dan Indopos.co.id yang menayangkan berita mengenai 'Ahok gantikan Ma'ruf Amin', telah melanggar Kode Etik Jurnalistik. Pelanggaran yang terjadi adalah terhadap Kode Etik Jurnalistik pasal 1,2,3,4, serta $5 \mathrm{a}$ dan 5c, mengenai pedoman pemberitaan media siber. Menurut keputusan Dewan Pers Nomor 18/Risalah/DP/II/2019 ditetapkan bahwa pemberitaan dengan judul tersebut dianggap melanggar karena tidak didasarkan pada informasi yang akurat, dan tidak professional. Indopos tidak melakukan pengecekan berulang terhadap pemberitaan tersebut dan berita tersebut informasi yang bohong atau fitnah. Sehingga berdasarkan keputusan tersebut, Indopos wajib memberikan hak jawab kepada Tim Kampanye Nasional Jokowi-Ma'ruf yang mengadukan masalah ini ke Dewan Pers, dan meminta maaf kepada TKN dan masyarakat. Atas keputusan tersebut, IndoPos menerima dan menjalankan keputusan Dewan Pers saat itu (CNN, 2019).

Contoh lain dan menjadi topik pemberitaan yang masih hangat dibicarakan sampai saat ini, yaitu mengenai covid 19. Beberapa waktu yang lalu, Dewan Pers memberikan himbauan kepada media massa untuk memperhatikan kepatuhan akan kode etik dalam peliputan kasus virus covid 19. Muhammad Muh, Ketua Dewan Pers menyampaikan media massa harus memperhatikan sejumlah 
ketentuan, dengan memegang teguh prinsip-prinsip Kode Etik Jurnalistik dan memperhatikan kepentingan publik yang lebih luas sebelum memuat berita atau laporan mengenai kasus virus corona. Media massa perlu menjaga ketertiban masyarakat sehingga dalam laporan dan kasus virus corona tidak menimbulkan kepanikan masyarakat. Selain itu media massa juga diminta untuk tidak memuat identitas pasien, yang dinyatakan positif, termasuk nama, foto atau alamat tinggalnya, karena hal itu merupakan privasinya (Katriana, 2020).

Masyarakat sebagai khalayak atau pembaca berita dimedia harus selalu memperhatikan atau mempertanyakan akurasi artikel berita di media online. Hal ini dikarenakan media dapar saja menayangkan sebuah artikel berita yang faktanya masih dipertanyakan, alias simpang siur kebenarannya. Bayangkan saja, jika pembaca berita di atas langsung mempercayai dan menyebarluaskan atau men-share link berita atau menyebutkan informasi dari salah satu media tersebut, maka akan muncul disinformasi yang berpotensi untuk menjadi hoax ditengah-tengah masyarakat.

Beberapa kasus di atas menunjukkan bahwa walaupun media online sudah terverifikasi dan secara resmi menjadi media yang dapat memproduksi berita, dan wajib untuk patuh terhadap idealisme profesi media, namun masih banyak yang lebih memprioritaskan berita yang lebih layak dijual. Hal ini menyebabkan media lebih mengedepankan banyaknya pageview dan click untuk mendapatkan pemasukan dari penjualan spot iklan yang lebih banyak atau memprioritaskan aspek komersialisme media.

Melihat situasi dan fenomena tersebut, tidaklah mengherankan jika media-media online di Indonesia dianggap menggunakan gaya penulisan artikel berita yang berbeda, yaitu berita yang ditayangkan 
secara sepotong-sepotong atau dipecah-pecah. Media online Indonesia kemudian dikenal sebagai jurnalisme empat paragraph, karena dalam satu artikel berita biasanya hanya memuat empat paragraf saja. Strategi penulisan berita yang dibuat hanya sepotong-sepotong ditujukan, untuk mewujudkan kecepatan penayangan berita (mengejar kuantitas berita) selain itu berita yang dibuat sepotong-potong tersebut akan menguntungkan karena secara langsung membuat pageview yang berlipatganda (Margianto dan Syaefullah, 2010). Jika kita membaca berita pada aplikasi media online, kita juga dapat menemukan berbagai judul artikel berita yang dipecah-pecah walaupun masih merupakan isi berita yang sama atau dapat digabungkan menjadi satu artikel berita. Gaya penulisan ini juga cenderung menjadi ciri khas penulisan berita di beberapa media online.

Selain itu, media online cenderung berkompetensi menjadi terdepan dalam menyampaikan informasi ter-update, sehingga beberapa informasi yang baru didapatkan oleh jurnalis, langsung ditayangkan dalam laman media online tersebut. Hal ini dilakukan, supaya tidak tertinggal dengan media online lainnya. Walaupun informasi tersebut belum lengkap atau belum jelas kebenarannya. Ya lagi-lagi seperti di atas, ini ditujukan untuk memperbanyak pageview yang didapatkan oleh media, termasuk traffic dalam situsnya. Artinya, karena berita ini belum lengkap maka pembaca yang sudah membaca berita sebelumnya cenderung akan mencari berita yang sama di situs media online tersebut.

Setiap media online menayangkan beritanya, sebenarnya media tersebut sedang menunjukkan kredibilitasnya dimata pembacanya. Oleh karena itu, kualitas berita dan pelanggaran-pelanggaran yang dilakukannya akan meruntuhkan kredibilitas media itu sendiri. Seharusnya setiap berita di media dapat merefleksikan cara peliputan, proses pengeditan berita dan sampai kepada penayangan berita tersebut. Seluruh proses tersebut harus sesuai dengan idealisme yang sudah ditentukan dalam Kode Etik 
Jurnalistik, tanpa harus menunggu adanya sanksi dan teguran dari Dewan Pers.

Merawat idealisme pada media online, tidak hanya memastikan apakah media tersebut sudah menjalankan fungsi dan perannya saja, namun adanya sebuah keseimbangan didalamnya. Media harus dapat memberikan informasi, mengedukasi, menghibur dan kontrol sosial, keempatnya adalah fungsi keberadaan pers yang harus ditampilkan secara berimbang. Tidak boleh fungsi menghibur dari sebuah berita ditayangkan secara menonjol sehingga mengabaikan fungsi -fungsi lainnya, misalnya terkait dengan berita yang menghibur akan tetapi berisi informasi yang tidak benar atau mengandung nilai-nilai yang tidak mendidik.

Hal lainnya termasuk masalah yang paling mencolok di media online adalah sangat mengedepankan aspek komersialisme. Media online dalam meliput, menulis dan menayangkannya hanya memperhatikan aspek layak jual saja, akan tetapi kurang memperhatikan apakah berita tersebut sudah memenuhi kategori layak tayang. Terkait hal tersebut adalah seorang Guru Besar Komunikasi Prof. Onong Uchjana Effendy, mengingatkan bahwa terdapat dua dimensi yang dapat mewujudkan pers yang ideal yaitu, aspek idealisme dan komersialisme. Pada satu sisi pers harus menjaga dan mengedepankan idealismenya di dalam melaksanakan kegiatan jurnalistiknya, disisi lain pers harus berusaha agar lembaganya tetap tumbuh dan berkembang (survival) (Akhyar, 2015). Sehingga sangat jelas bahwa di dalam kerja jurnalistik maka media harus mengedepankan idealismenya walau juga harus berusaha agar secara ekonomi lembaganya dapat terus tumbuh dan bertahan.

Memperingati World Press Freedom Day 2021, untuk kedua kalinya dalam situasi pandemi covid 19, semakin banyak kritik maupun harapan yang disampaikan masyarakat atau pengguna media 
terhadap seluruh aktifitas, kegiatan maupun peran media. Hal tersebut terjadi karena situasi pandemi membuat begitu meningkatnya informasi maupun berita yang hendak disampaikan kepada publik, termasuk kebijakan maupun perkembangan pandemi saat ini. Berbagai data, masukan maupun kritik yang diberikan dalam tulisan ini, diharapkan dapat menjadi refleksi untuk merawat idealisme di media khususnya di industri media online. Kita berharap idealisme tersebut dapat semakin terawat, bukan semakin memudar.

\section{Referensi}

Akhyar, T. (2015). Manajemen Pers: Antara Idealisme dan Komersialisme. Jurnal Intizar 21 (1). Diperoleh dari http://jurnal.radenfatah.ac.id/index.php/intizar/article/view/294

AS, Sumadiria. (2006). Jurnalistik Indonesia Menulis Berita dan Feauture. Bandung : Simbiosa Rekatama Media.

CNN. (2019). Dewan Pers: Berita 'Ahok Gantikan Ma'ruf' Langgar Kode Etik.

Diperoleh dari

https://www.cnnindonesia.com/nasional/20190222194255-20-

371944/dewan-pers-berita-ahok-gantikan-maruf-langgar-kode-etik

Dewan Pers. (2017). Buku Saku Wartawan. Diperoleh dari https://dewanpers.or.id/assets/ebook/buku/1905160429_201708_BUKU_Saku_Wartawan_Cetakan_ke-7.pdfHadiyat, Y, D. (2019). Clickbait di Media Online Indonesia. Jurnal Pekommas, 4(1). Diperoleh dari

https://jurnal.kominfo.go.id/index.php/pekommas/issue/view/199

Katriana. (2020). Soal Covid-19, Dewan Pers Imbau Media Patuhi Kode Etik Jurnalistik.

Diperoleh dari

https://www.antaranews.com/berita/1336898/soal-covid-19-dewanpers-imbau-media-patuhi-kode-etik-jurnalistik

Kertanegara, M, R. (2018). Penggunaan Clickbait Headline pada Situs Berita dan Gaya Hidup Muslim Dream.co.id. Jurnal Komunikasi Mediator, 11(1). Diperoleh https://ejournal.unisba.ac.id/index.php/mediator/article/view/2751/p df. 
Martini, R. (2014). Analisis Peran dan Fungsi Pers Sebelum dan Sesudah Reformasi Politik di Indonesia. Jurnal Ilmu Sosial 13(2). Diperoleh dari https://media.neliti.com/media/publications/101204-ID-analisisperan-dan-fungsi-pers-sebelum-d.pdf

Margianto, J, H., dan Syaefullah, A. (2010). Media Online: Antara Pembaca, Laba dan Etika. Aliansi Jurnalis Independen Indonesia. Jakarta. Diperoleh dari https://aji.or.id/upload/article_doc/Media_Online.pdf

Rizkinaswara, L. (2019). Sinergi Penataan Media Siber, Ditjen Aptika dan Dewan Pers buat PKS. Diperoleh dari https://aptika.kominfo.go.id/2019/04/sinergi-penataan-media-siberditjen-aptika-dan-dewan-pers-buat-pks/

Undang-Undang Pers No.40 (1999). Diperoleh dari https://peraturan.bpk.go.id/Home/Details/45370/uu-no-40-tahun1999

Wiryono, S. (2020). Hanya WNA China yang diberi Izin Tinggal Darurat di Indonesia karena Virus Corona. Diperoleh dari https://megapolitan.kompas.com/read/2020/03/12/10264191/hanya -wna-china-yang-diberi-izin-tinggal-darurat-di-indonesia-

karena?page=all

\section{Profil Penulis}

Lamria Raya Fitriyani, merupakan dosen dan peneliti di Institut Komunikasi dan Bisnis LSPR. Selain itu juga tergabung dalam Jaringan Pegiat Literasi Digital (Japelidi) Indonesia. Mendapat gelar master komunikasi dari LSPR Jakarta. Buku yang sudah pernah ditulis berjudul Cara Bijak Menggunakan Dompet elektronik (2021), Merangkai Asa untuk Media Massa (2021), Panduan Menjadi Jurnalis Warga yang Bijak Beretika (2019) dan Mencegah dan Mengatasi Bullying di Dunia Digital (2019). Minat risetnya adalah bidang komunikasi, komunikasi budaya, media, personal branding, marketing komunikasi, public relations dan komunikasi organisasi. Email: lamria.rf@lspr.edu 